Population and Social Characteristics of the Tamarao (Bubalus mindorensis) Author(s): David W. Kuehn

Source: Biotropica, Vol. 18, No. 3 (Sep., 1986), pp. 263-266

Published by: The Association for Tropical Biology and Conservation

Stable URL: http://www.jstor.org/stable/2388495

Accessed: 10/06/2014 13:57

Your use of the JSTOR archive indicates your acceptance of the Terms \& Conditions of Use, available at

http://www.jstor.org/page/info/about/policies/terms.jsp

JSTOR is a not-for-profit service that helps scholars, researchers, and students discover, use, and build upon a wide range of content in a trusted digital archive. We use information technology and tools to increase productivity and facilitate new forms of scholarship. For more information about JSTOR, please contact support@jstor.org. 


\title{
Population and Social Characteristics of the Tamarao (Bubalus mindorensis) ${ }^{1}$
}

\author{
David W. Kuehn²
}

U.S. Peace Corps, Philippine Bureau of Forest Development, Quezon City, Republic of the Philippines

\begin{abstract}
A minimum of 51 tamarao (Bubalus mindorensis) occurred in a $20-\mathrm{km}^{2}$ study area at the Mt. Iglit Game Refuge and Bird Sanctuary, Occidental Mindoro, the Philippines. Juvenile bull tamarao formed groups similar to those in juvenile water buffalo (Bubalus bubalis), but adult tamarao did not form clans or aggregations like buffalo.
\end{abstract}

THE TAMARAO WAS KNOWN long before it was described (Heude 1888, Steere 1888), but it frequently was confused with the anoa (Bubalus [Anoa] depressicornis, Bubalus [Anoa] quarlesi) (Everett 1878). Taxonomists now agree that the tamarao is a member of the genus Bubalus, but Bohlken (1958) considered it a subspecies of the water buffalo, and Groves (1969) more recently accorded it specific status.

Although tamarao occurred on Luzon during the Pleistocene (Beyer 1957), during historic times they have been restricted to the island of Mindoro in the Philippines. Tamarao have been legally protected since 1936, but Harper (1945) warned that the species faced early extinction primarily due to habitat destruction and poaching. Numbering perhaps 10,000 in 1900 (Harrisson 1969a), the tamarao population decreased to about 1000 in 1949 and 244 in 1953 (Manuel 1957). By 1969 only 100 tamarao were believed to inhabit four regions in Mindoro (Harrisson 1969b, Alvarez 1970).

The $90-\mathrm{km}^{2} \mathrm{Mt}$. Iglit Game Refuge and Bird Sanctuary was established in one of the four Mindoro regions in 1961 and was enlarged to $755 \mathrm{~km}^{2}$ in 1969. Talbot and Talbot (1966) estimated a minimum of 17 tamarao survived at Mt. Iglit in 1964; five years later Harrisson (1969b) estimated at least 20 remained.

This paper offers criteria for estimating the age of tamarao in the field, documents population characteristics of tamarao on a $20-\mathrm{km}^{2}$ study area at Mt. Iglit, and compares the behavior of tamarao, whose range was heavily forested before human arrival (Landicho 1952, Wernstedt \& Spencer 1967), with that of the water buffalo, which is adapted to more open habitat (Halder 1973).

\footnotetext{
${ }^{1}$ Received 22 October 1984, revision accepted 16 April 1985.

${ }^{2}$ Present address: Forest Wildlife Populations and Research Group, Minnesota Department of Natural Resources, 1201 East Highway 2, Grand Rapids, Minnesota 55744, U.S.A.
}

\section{STUDY AREA}

The study area lies in the foothills of the mountain range that runs through Mindoro's interior and includes $20 \mathrm{~km}^{2}$ of the Mt. Iglit Refuge east of the refuge headquarters. Elevation ranges from 300 to $1000 \mathrm{~m}$. Most of the study area is comprised of several ridges, and it is bounded by ranges of steep ridges to the north, east, and south. Two rivers flow year round and several streams flow only in the rainy season.

Grassland covers 90 percent of the study area, and three grassland types are very common. Talahib (Saccharum spontaneum) dominates the wettest areas in stands up to $4 \mathrm{~m}$ high. Cogon (Imperata spp.) dominates somewhat dryer areas. A complex of shorter grasses, including Themeda spp., Paspalum spp., and Alloteropsis semialata, dominates the upper slopes of the ridges. Reeds (Phragmites spp.) occur along the rivers. Bamboo (Dinocbloa spp. and Schizostachyum spp.) and secondary dipterocarp forests occur along the rivers and wherever the topography causes a firebreak effect (Talbot \& Talbot 1966, Philippine Bureau of Forest Development, pers. comm.). Members of the Batangan tribe burn most of the grassland every dry season. The study area has a dry season from December through May and a rainy season from June through November. Rainfall averages $300 \mathrm{~cm}$ annually in Occidental Mindoro (Landicho 1952).

\section{METHODS}

Field work was conducted on 221 days during 3-7 May 1972, 3 September 1972 through 18 July 1973, and 4 November 1973 through 22 March 1974. Areas around vantage points were scanned with binoculars and spotting scope to observe tamarao. Adult (older than 5 years) cow tamarao were individually identified by horn conformation and by the number, age, and sex of their calves. Most adult bulls could not be individually recognized, and the estimate of their numbers is based on times and 
areas of observations. In examining group size tamarao were counted once during each day they were observed.

\section{RESULTS}

AgING CRITERIA.-Provisional criteria were developed to estimate age of tamarao from pelage color and from horn length and conformation. A neonate tamarao was reddish-brown with dark brown legs and a black dorsal line. Calves a few months old had light brown bodies which later turned dark brown or a slate color. A captive cow and bull developed slate-colored pelage at 3-4 yr ( J. M. Buenaflor, pers. comm.). In most animals the slate-colored pelage darkened to black, but three adult cows were brown or brown-tinged. Two bulls turned black a year after they developed slate-colored pelage.

Observations of horn growth in cow tamarao were made on one calf from the age of a few days to 9 months, and on two others from age 1 to $2 \mathrm{yr}$ and from 3 to $4 \mathrm{yr}$. The age of the second calf was estimated by comparing her horn growth to that of the first calf, and the age of the last calf was established when it developed slate-colored pelage at an assumed age of $3.5 \mathrm{yr}$. At an assumed age of $1 \mathrm{yr}$ the second calf s horns reached the middle of her ears when the ears were parallel to them; at $2 \mathrm{yr}$ of age her horns reached two-thirds of the distance to the ear tips. The horns of the oldest calf were longer but still spike-like at $3 \mathrm{yr}$, and at $4 \mathrm{yr}$ they started to broaden at the bases, approaching adult conformation.

At $2 \mathrm{yr}$ of age, estimated from pelage changes, the horns of two bulls reached their ear tips. At $3 \mathrm{yr}$ their horns extended past the ear tips, and in one animal the bases of the horns were broadening. At $4 \mathrm{yr}$ of age the horns of both bulls were wedge-shaped with broad bases and narrow terminal halves. The horns of two other bulls were still wedge-shaped at $5 \mathrm{yr}$ of age, estimated from pelage changes.

Population estimate.-Fifty-one different tamarao were counted during the December-May dry season of 19721973 (Table 1). The sex ratio was approximately equal (9 males: 10 females) among tamarao not more than 4.5 yr old. If the number of adult cows equalled the estimated 16 adult bulls, and if they averaged 1.6 calves at heel (Table 2), a minimum of 67 tamarao occupied the 20$\mathrm{km}^{2}$ study area.

SOCIAL CHARACTERISTICS. - Adult bull tamarao were largely solitary. Of 218 observations, 179 (82\%) were of lone bulls, $33(15 \%)$ were of bulls with cows, and $5(2 \%)$ were of bulls with independent tamarao less than $4 \mathrm{yr}$ old. The largest aggregation observed included an adult bull, a cow and calf, and three bulls not more than 3.5 yr old.

Four juvenile tamarao were frequently seen together.
TABLE 1. Sex and estimated age of tamarao observed during December 1972-May 1973.

\begin{tabular}{cccc}
\hline Age in years & Bulls & Cows & $\begin{array}{c}\text { Unknown } \\
\text { sex }\end{array}$ \\
\hline 0.5 & 0 & 1 & 5 \\
1.5 & 1 & 2 & 1 \\
2.5 & 4 & 2 & 0 \\
3.5 & 3 & 2 & 0 \\
4.5 & 1 & 3 & 0 \\
$\geq 5.5$ & 16 & $\underline{10}$ & $\frac{0}{6}$ \\
Total & 25 & 20 & 6 \\
\hline
\end{tabular}

Two bulls were 3-4 yr old and two were 4-5 yr old in January-July 1973. In that period only 4 (18\%) of 22 observations of the group were of lone animals, compared to 8 (47\%) of 17 observations from November 1973 through March 1974.

Cow tamarao were alone or accompanied by up to three calves in $71(66 \%)$ of 107 observations, and were with bulls in 33 (31\%), 4 of them involving courtship. Only one recurrent association between adult cows was observed: two cows, each with one calf, were seen together 6 times and separate twice over 16 months. In the only other associations, a cow with three calves was seen once with a calfless cow, and a cow with one calf was briefly associated with an adult bull and three juvenile bulls.

Five young tamarao calves were seen, including a neonate on 2 June 1973 and one estimated at 1-2 weeks old on 18 October 1972. The birthdates of three calves seen in November 1972 and 1973 were estimated as being in August-September, so births may occur throughout Mindoro's June-November rainy season. In the only prolonged observation of a neonate, a tamarao cow grazed $50 \mathrm{~m}$ away while the calf lay with her neck stretched on the ground, a posture typical of the "hider" species (Lent 1974) which hide their young rather than accompanying them constantly.

The oldest male calves still in family groups were estimated to be $3 \mathrm{yr}$ old, and two apparently independent males were $2 \mathrm{yr}$ old. Female calves up to 4.5 years old (Table 2) were observed in family groups, and two females appeared to be independent at 1.5 and $2.5 \mathrm{yr}$ of age; another female was driven off by her mother at $3.5 \mathrm{yr}$.

Agonistic beHAvior.-No fights between bull tamarao were observed, but 8 pursuits of one bull by another were seen. One incident occurred $2 \mathrm{hr}$ after breeding activity was observed nearby, but the cow was not present when the bulls came into conflict. Four incidents occurred after fires had cleared most of the cover from an expanse of grassland and the tamarao had converged on the unburned areas. In 2 incidents an adult bull chased off two 
TABLE 2. Sex and estimated age of offspring accompanying cow tamarao during December 1972-May 1973.

\begin{tabular}{clll}
\hline Cow & \multicolumn{2}{c}{ Sex and estimated age of calves } \\
\hline 1 & - & & \\
2 & - & & \\
3 & $\mathrm{f}-0.5$ & & \\
4 & $?-0.5$ & & \\
5 & $?-1.5$ & $\mathrm{f}-4.5$ & $\mathrm{f}-4.5$ \\
6 & $?-0.5$ & $\mathrm{~m}-1.5$ & $\mathrm{f}-2.5$ \\
7 & $\mathrm{f}-1.5$ & $\mathrm{~m}-2.5$ & $\mathrm{f}-4.5$ \\
8 & $?-0.5$ & $\mathrm{~m}-2.5$ & $\mathrm{~m}-5$ \\
9 & $?-0.5$ & $?-0.5$ &
\end{tabular}

$\mathrm{m}=$ male. $\mathrm{f}=$ female. $?=$ unknown sex. Numeral $=$ age in years.

juveniles which had moved beyond their previously observed range. In the only incident observed in its entirety, one bull pursued another for $1 \mathrm{~km}$ after encountering it unexpectedly in dense cover. The observed portions of the other pursuits were also long, ranging from 100 to 700 $\mathrm{m}$ and averaging $300 \mathrm{~m}$.

Tamarao were not observed to use earthtossing or vertical head movements as threats like those Tulloch (1978) observed in water buffalo. In 6 incidents cow tamarao expressed threats by lowering their heads with the horns nearly vertical and shaking the horns laterally, similar to the threat posture in domestic cattle (Hafez \& Schein 1962). One cow chased her calf and horned it severely, another prodded a calf with her horns, and a third lowered her head with horns vertical and walked at a calf.

\section{DISCUSSION}

The population density at Mt. Iglit, at least 51 tamarao on the $20-\mathrm{km}^{2}$ study area, should not be applied to other areas because much of Mindoro is very rugged and unsuitable as tamarao habitat. Also, few areas are as well protected against poaching as the study area, which has had resident game wardens since 1969 . The age structure of the tamarao population suggests the herd has increased steadily since then.
Adult tamarao are much less social than water buffalo. Associations of adult bull tamarao were not observed, and in 8 incidents bull tamarao were observed purusing other bulls, indicating that the absence of aggregations is not due solely to the small remaining population of tamarao. Only 1 recurrent association of cow tamarao was observed. In contrast, bull buffalo may form groups of up to 50, and generations of cow buffalo form clans numbering up to 30 animals. The clans may combine in herds of up to 500 buffalo (Tulloch 1978). The group of 4 juvenile bulls observed was similar to the groups 2- to 3-year-old bull buffalo form after they are expelled from family groups (Tulloch 1979).

Male tamarao older than $3 \mathrm{yr}$ and females older than 4.5 years were not observed in family groups. An adult bull tamarao attacked a 2.5-yr-old male calf which mounted a cow; this behavior is similar to that in buffalo, where an adult bull drives off 2- to 3-yr-old males when a cow in the clan is in estrus (Tulloch 1979). A cow tamarao was observed driving off her 3.5-yr-old female calf, indicating that the small size of tamarao family groups, compared to the buffalo's clans, is actively maintained. The observation of a tamarao cow grazing $50 \mathrm{~m}$ from her neonate also indicates that a different cow-calf relationship occurs in tamarao than in buffalo; buffalo cows do not range that far from their calves until the third month (Tulloch 1979).

The lesser sociability of tamarao than of buffalo may be an adaptation to a forest habitat (Eisenberg 1966), in contrast to buffaloes' adaptation to more open habitat (Halder 1973). The social characteristics of the tamarao may resemble those of the anoa, another poorly known forest buffalo, but the tamarao is more solitary than other bovines (Nowak \& Paradiso 1983).

\section{ACKNOWLEDGMENTS}

I thank T. K. Fuller, Minnesota Department of Natural Resources, for reviewing the manuscript, and J. B. Alvarez, Philippine Bureau of Forest Development, and the staff of the Mt. Iglit Game Refuge and Bird Sanctuary, for supporting this study. The study was funded by the U.S. Peace Corps-Smithsonian Institution Environmental Program and the Philippine Bureau of Forest Development.

\section{LITERATURE CITED}

Alvarez, J. B., JR. 1970. Philippine tamaraw: here to stay. IUCN Publ. N. S. 18: 46-51.

Beyer, H. O. 1957. New finds of fossil mammals from the Pleistocene strata of the Philippines. Natl. Res. Counc. Philippines Bull. 41: 220-239.

BohlKen, H. 1958. Vergleichende untersuchungen an wildridern (Tribus Bovini Simpson 1945). Zool. Jahrb. (Phys.) 68: 113202.

EISENBERG, J. F. 1966. The social organizations of mammals. Handb. Zool. 10: 1-92.

Everett, A. H. 1878. Letter. Proc. Zool. Soc. London 1878: 792. 
Groves, C. P. 1969. Systematics of the anoa (Mammalia, Bovidae). Beaufortia 17: 1-12.

Hafez, E. S. E., AND M.W. Schein. 1962. The behaviour of cattle. In E. S. E. Hafez (Ed.). The behavior of domestic animals, pp. 247-296. Williams and Wilkins Co., Baltimore.

HALDER, U. 1973. Ecological aspects of social organisation in banteng (Bos javanicus) and feral buffalo (Bubalus bubalis) in Java. Eleventh Int. Congr. Game Biol.: 159-164.

Harper, F. 1945. Extinct and vanishing mammals of the old world. Am. Comm. Int. Wildl. Protection Special Publ. No. 12, pp. 548-550.

HARrisson, T. 1969a. The tamaraw and its survival. IUCN Bull. N. S. 2: 85-86.

- 1969b. The tamaraw and Philippine conservation. Biol. Cons. 1: 317-318.

Heude, P. M. 1888. Note sur le petit buffle sauvage de líle de Mindoro (Philippines). Memoires concernant l'histoire naturelle de l'Empire chinois. 2: 4, 50.

LANDicho, M. Z. 1952. The Mindoro yearbook. Yearbook Publishers, Manila.

LENT, P. C. 1974. Mother-infant relationships in ungulates. In V. Geist and F. Walther (Eds.). IUCN Publ. N. S. 24, The behavior of ungulates and its relation to management, pp. 14-55. IUCN, Morges, Switzerland.

Manuel, G. C. 1957. Status of tamaraw, Anoa mindorensis (Heude). Proc. Eighth Pacific Sci. Cong. 3A: 1463-1474.

Nowak, R. M., AND J. L. Paradiso (Eds.). 1983. Walker's mammals of the world. Johns Hopkins Univ. Press, Baltimore and London.

Steere, J. B. 1888. Letter. Proc. Zool. Soc. London 1888: 413-415.

TAlbot, L. M., AND M. H. TALBOt. 1966. The tamarau (Bubalus mindorensis [Heude]). Observations and recommendations. Mammalia 30: 1-12.

Tulloch, D. G. 1978. The water buffalo, Bubalus bubalis, in Australia: grouping and home range. Aust. Wildl. Res. 5: 327354.

. 1979. The water buffalo, Bubalus bubalis, in Australia: reproductive and parent-offspring behavior. Aust. Wildl. Res. 6: $265-287$.

Wernstedt, F., and J. Spencer. 1967. The Philippine Island world. Univ. of California Press, Berkeley.

\section{SLIDES OF TROPICAL MAMMALS AVAILABLE}

Slides of both tropical and temperate zone mammals are available from The Mammal Slide Library, a non-profit educational service of The American Society of Mammalogists. The 1986/87 catalog lists nearly 900 slides of mammals depicting 605 species in 400 genera, 102 families and 19 orders. The diversity of subjects and low expense (\$1.00 per slide) makes this collection a unique and valuable resource for a wide variety of educational and research applications. Slide lists are available free of charge, and the complete catalog (with slide descriptions) costs $\$ 2.00$ (\$4.00 outside the U.S.A., Canada and Mexico). For more information or to order a catalog write to: Mammal Slide Library, Dept. of Biology, State University of New York, Oswego, NY, 13126, U.S.A. 